\title{
Subclinical perfusion deficits in patients with Type 2 diabetes detectable with Cardiovascular Magnetic Resonance Imaging
}

\author{
Anna Schmidt ${ }^{*}$, David Lau², Matthias G Friedrich ${ }^{3}$ \\ From 2011 SCMR/Euro CMR Joint Scientific Sessions \\ Nice, France. 3-6 February 2011
}

\section{Background}

An estimated 200 million people worldwide have type 2 diabetes. Type 2 diabetes is recognized as an independent risk factor for adverse cardiac events, such as myocardial infarction. Cardiovascular disease is the leading cause of death amongst diabetic patients. The subclinical pathophysiology of diabetic heart disease predicts global microvascular disease, prior to the onset of overt ischemic heart disease. Non-invasive screening methods are therefore important for risk stratification of asymptomatic patients. Cardiovascular Magnetic Resonance Imaging (CMR) is a valuable tool for the assessment of subclinical microvascular function in this high-risk population.

\section{Objectives}

To assess the degree of cardiac microvascular dysfunction in individuals type 2 diabetes (T2D) without coronary disease or hypertension, compared to healthy, nondiabetic controls.

\section{Methods}

This cross sectional pilot data included 2 groups of subjects: Patients diagnosed with type 2 diabetes $\left(\mathrm{Hb}_{\mathrm{A} 1 \mathrm{c}}\right.$ 7.5-9.9\%; mean age 59.3 $\pm 7.17 ; \mathrm{n}=6)$, and healthy, non-diabetic age-matched controls (mean age 51.9 \pm 10.3 ; $\mathrm{n}=10$ ). Medical history and ECG were reviewed to rule out ischemic heart disease. Qualified patients underwent a CMR-Adenosine stress perfusion,

\section{Results}

Subendocardial perfusion delays were observed in 4 out of 6 diabetic patients, and 0 of 10 healthy controls $(\mathrm{p}<0.05)$.

${ }^{1}$ Stephenson CMR Center, University of Calgary, Calgary, AB, Canada Full list of author information is available at the end of the article

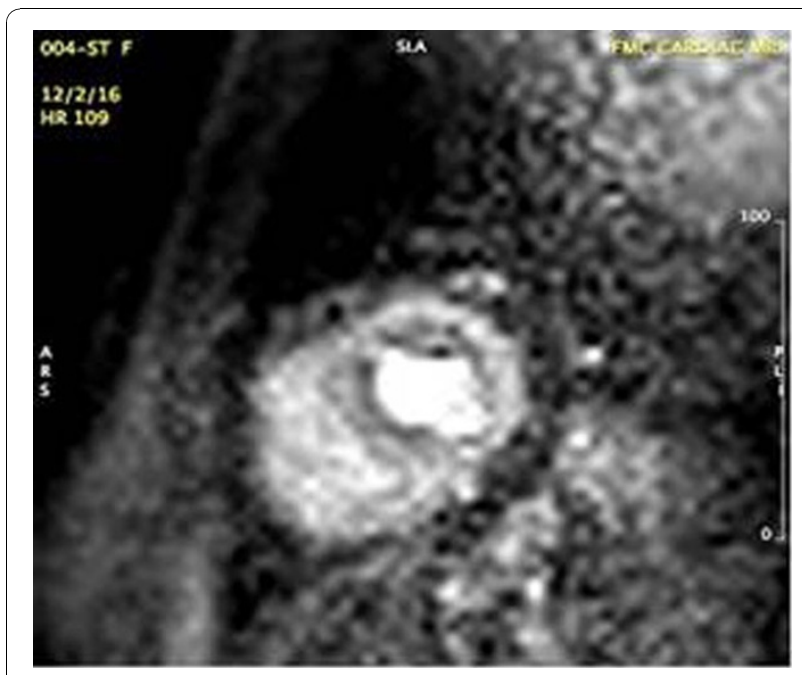

Figure 1 Stress perfusion image from patient diagnosed with a type 2 diabetes in 2009. Note circumferential subendocardial perfusion delay. 
are required to assess the pathophysiologic context and prognostic impact of these findings.

\section{Author details}

${ }^{1}$ Stephenson CMR Center, University of Calgary, Calgary, AB, Canada.

${ }^{2}$ Stephenson CMR Centre, University of Calgray, Calgary, AB, Canada.

${ }^{3}$ Stephenson CMR Centre, University of Calgary, Calgary, AB, Canada.

Published: 2 February 2011

doi:10.1186/1532-429X-13-S1-P129

Cite this article as: Schmidt et al: Subclinical perfusion deficits in

patients with Type 2 diabetes detectable with Cardiovascular Magnetic

Resonance Imaging. Journal of Cardiovascular Magnetic Resonance 201113

(Suppl 1):P129.

Submit your next manuscript to BioMed Central and take full advantage of:

- Convenient online submission

- Thorough peer review

- No space constraints or color figure charges

- Immediate publication on acceptance

- Inclusion in PubMed, CAS, Scopus and Google Scholar

- Research which is freely available for redistribution

Submit your manuscript at 